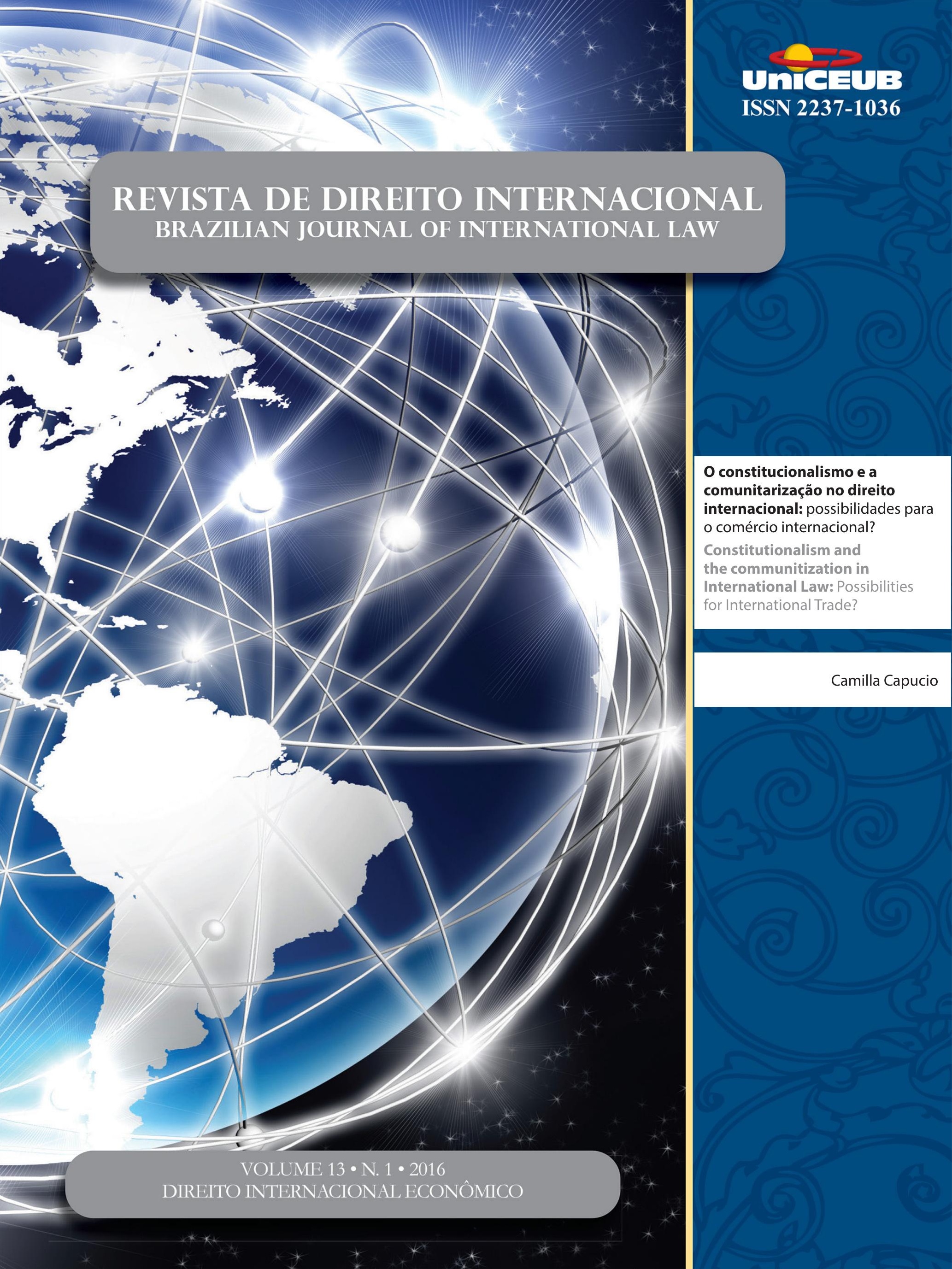




\section{Sumário}

Dossiê Temático: Direito Internacional Econômico.........................................................1

EDITORIAL:

Resultados da III Conferência Bienal da Red DEI ................................................. 3

Michelle Ratton Sanchez-Badin (em nome da Diretoria da Red DEI), Fabio Costa Morosini e Lucas da Silva Tasquetto (em nome dos organizadores da III Conferência da Red DEI)

Direito Internacional Econômico no Brasil: QUem Somos E o QUE faZemos? EvidênCIas EMPÍRICAS DE 1994 A 2014

Michelle Ratton Sanchez Badin, Fabio Costa Morosini e Inaê Siqueira de Oliveira

UM ESPAÇO PARA PENSAR EM ALTERNATIVAS? A ACADEMIA LATINO-AMERICANA DE DIREITO INTERNACIONAL ECONÔMICO FRENTE À ORDEM ECONÔMICA GLOBAL

Nicolás Marcelo Perrone

Grupo de alto Nível Brasil - Urugua (GAN): um Novo paradigma para a INTEgraÇão PRODUTIVA NO MERCOSUL

Alebe Linhares Mesquita e Vivian Daniele Rocha Gabriel

O COMÉRCIO de SERVIÇOS ENTRE Brasil E URUGUAI: LiberalizaÇÃo, DESAFIOS E PERSPECTIVAS DO SETOR DE TECNOLOGIA DA INFORMAÇÃO E COMUNICAÇÃO (TIC) E SOFTWARES

Vivian Daniele Rocha Gabriel e Alebe Linhares Mesquita

Core Labor Standards No Regime de PREFERÊNCIAS TARIFÁrias No MERCOSUL: A NeCESSIDADE DE HUMANIZAÇÃO DO COMÉRCIO INTERNACIONAL

Martinho Martins Botelho e Marco Antônio César Villatore

ACordo TRIMS: FleXibilizaÇão ou Não? Política de CONTEÚdo loCal, PROCESSO PROdUTIVO BÁSICO (PPB) E OS DESAFIOS PARA A INDÚSTRIA BRASILEIRA E A INTEGRAÇÃo LATINO-AMERICANA 100

Natália Figueiredo 
ESTUDIOS DE CASO DE RECHAZOS EN FRONTERA DE EXPORTACIONES ALIMENTARIAS LATINOAMERICANAS POR MOTIVOS RELACIONADOS CON MEDIDAS TÉCNICAS NO ARANCELARIAS.

Sofía Boza, Juan Rozas e Rodolfo Rivers

América do Sul em face dos tratados bilaterais de inVESTimento: RUMO aO RETORNo do EsTADO NA SOLUÇão DE CONTROvÉRSIAS? 133 Magdalena Bas

FutURo DE LOS SISTEMAS NACIONALES DE CIENCIA TECNOLOGÍA E INNOVACIÓN EN LA AGENDA ECONÓMICA DE AMÉRICA LATINA: DEFINIENDO CAMBIOS REGULATORIOS O PROTEGIENDO INVERSIONES 146

Rodrigo Corredor

EL PAPEL DE LAS INSTITUCIONES DE CONTROL FINANCIERO SOBRE LOS DERECHOS HUMANOS EN EL CONTEXTO LATINOAMERICANO 157 Jose Miguel Camacho Castro

CONVERGENCIA REgUlATORIA EN LA ALIANZA DEL PACÍFICO: UN CAPÍTULO INCONCLUSO 170 Rodrigo Polanco Lazo

O CONSTITUCIONALISMO E A COMUNITARIZAÇÃO NO DIREITO INTERNACIONAL: POSSIBILIDADES PARA O COMÉRCIO INTERNACIONAL?

Camilla Capucio

ESCASSEZ HÍDRICA E DIREITO INTERNACIONAL ECONÔMICO: O BRASIL COMO PROTAGONISTA NA TRANSFERÊNCIA DE ÁGUA PARA REGIÕES ÁRIDAS

Douglas de Castro

A Segurança energética como base para maior integração na América Do Sul: à espera DE UM TRATADO MULTILATERAL

Matheus Bassani

Outros Artigos. 246

As PRÁtICAS RESTRITIVAS DA CONCORRÊNCIA NO MERCADO DE CONTRATAÇÃo PÚBLICA EUROPEU .. 248 Alice Rocha da Silva e Ruth M. P. Santos 
Do TRANSNACIONAL PARA O NACIONAL: IOSCO, O MERCADO DE VALORES MOBILIÁRIOS BRASILEIRO E ACCOUNTABILITY

Salem Nasser, Nora Rachman e Viviane Muller Prado

MigRaÇÃo de TRABALHADORES INTELECTUAIS BRASILEIROS PARA O MERCADO INTERNACIONAL: IDENTIFICAÇÃO DE ATOS DE ALICIAMENTO DE EMPREGADOS E MECANISMOS LEGAIS PARA IMPEDIR A APROPRIAÇÃo TECNOLÓGICA E CONCORRÊNCIA DESLEAL ..........................................285 José Carlos Vaz e Dias e João Marcelo Sant'Anna da Costa

THE EASIER WAY TO HAVE "BETTER LAW"? THE MOST-SIGNIFICANT-RELATIONSHIP DOCTRINE AS THE FALLBACK CONFLICT-OF-LAW RULE IN THE PEOPLE'S REPUBLIC OF CHINA

Chi Chung

REFLEXOS JURÍDiCOS DA GOVERNANÇA GLOBAL SUBNACIONAL: A PARADIPLOMACIA E O DIREITO INTERNACIONAL: DESAFIO OU ACOMODAÇÃO 320

Valéria Cristina Farias e Fernando Rei

Matrizes Políticas da JUSTiÇA PENAL INTERNACIONAL. 341 Francisco Rezek

RESPONSABILIDAD INTERNACIONAL DEL ESTADO FRENTE A LUCHA CONTRA LA DISCRIMINACIÓN RACIAL Y ÉTNICA EN ESPAÑA. 348

Edilney Tomé da Mata e Eduardo Biacchi Gomes Correio

The Peace Process in Sierra Leone: an analysis on marriages between culture and CRIME

Gustavo Bussmann Ferreira

Funcionalização e expansão do Direito Penal: o Direito Penal negocial ...............376 Antonio Henrique Graciano Suxberger e Dermeval Farias Gomes Filho

Proteção Internacional do Consumidor e Cooperação Interjurisdicional .396 Héctor Valverde Santana e Sophia Martini Vial

The land rights of indigenous and traditional peoples in Brazil and Australia.... 418 Márcia Dieguez Leuzinger e Kylie Lyngard 
The reception of European ideas in Latin America: the issue of the German sources in Tobias Barreto, A Prominent nineteenth CENTURy BraZilian legal scholar........439 Arnaldo Sampaio de Moraes Godoy

Normas Editoriais ..................................................................................... 461 


\title{
O constitucionalismo e a comunitarização no direito internacional: possibilidades para o comércio internacional?*
}

\author{
Constitutionalism and the communitization \\ in International Law: Possibilities for \\ International Trade?
}

Camilla Capucio**

\section{Resumo}

O presente trabalho objetiva apresentar o constitucionalismo como uma perspectiva de atualização e reinterpretação do Direito Internacional, em especial em sua aplicação ao comércio internacional. A pesquisa adota uma abordagem diagnóstica e descritiva, identificando a emergência de tal perspectiva a partir de fontes bibliográficas contrapostas aos fenômenos identificáveis na realidade internacional. Em um contexto internacional de juridificação e jurisdicionalização do comércio internacional, a teoria do constitucionalismo aplicada a essa esfera tem o valor de consolidar-se como matriz teórica capaz de integrar a Organização Mundial de Comércio ao sistema jurídico internacional de maneira mais ampla. Como consequência teórica, a comunitarização dessa organização poderia se apresentar como nova opção de aproveitamento de sua relevância nas relações internacionais. O trabalho se divide em cinco partes, que cumprem respectivamente as seguintes funções: (i) introdução do contexto teórico e dos elementos centrais do trabalho; (ii) apresentação da busca pela construção de uma comunidade internacional como um elemento norteador da mudança de paradigma no Direito Internacional, (iii) explicitação do paradigma constitucionalista do Direito Internacional como opção para interpretação sistêmica da ordem jurídica internacional; (iv) discussão teórica e aplicabilidade dessas noções ao sistema multilateral de comércio e (v) avaliação do arcabouço teórico e convite à reflexão sobre a temática.

Palavras-chave: Constitucionalismo. Comunitarização. Comércio internacional. Sistema multilateral. Organização Mundial do Comércio. OMC.

* Recebido em 01/11/2015

Aprovado em 25/02/2016

** Doutora em Direito Internacional (Faculdade de Direito da USP), Mestre e Graduada em Direito (Faculdade de Direito da UFMG). Pesquisadora do Núcleo de Estudos em Tribunais Internacionais (NETI-USP). Coordenadora do Grupo de Pesquisa Empresa, Mercado e Desenvolvimento Social (UNA). Professora (Centro Universitário UNA). Advogada. E-mail: camillacapucio@gmail.com

\section{Abstract}

This paper aims to present constitutionalism as an update and reinterpretation perspective of international law, especially in its application to international trade. The research adopts a diagnostic and descriptive approach, identifying the emergence of such a perspective from academic sources opposed to identifiable phenomena in international reality. In an international context of legal regulation an increasing juridical and judicial nature of in- 
ternational trade, constitutionalism aproach applied to this sphere may be identified as a theoretical framework capable of integrating the World Trade Organization to the international legal system in a more broad perspective. As a theoretical consequence, the communitarization of the organization could be presented as a new benefit option of its relevance in international relations. The paper is developed in five sections, which respectively fulfill the following functions: (i) introduction of the theoretical background and the central elements of the paper; (ii) presentation of the search for an international community as a guiding element of the paradigm shift in international law, (iii) clarification of international law constitutional paradigm as an option for systemic interpretation of international law; (iv) theoretical discussion and applicability of these notions to the multilateral trading system and (v) evaluation of the theoretical framework and call for reflections over this aproach.

Keywords: Constitutionalism. Communitarization. International Trade. Multilateral system. World Trade Organization. WTO

\section{INTRODUÇÃO: JURIDIFICAÇÃO E JURISDICIONALIZAÇÃo do COMÉRCIO INTERNACIONAL}

Em um contexto de "adensamento de juridicidade" das relações internacionais e de institucionalização crescente do Direito Internacional, ${ }^{1}$ observa-se, na realidade atual, aspectos como a internacionalização de áreas e de temas que antes estavam reservadas ao exclusivo domínio dos Estados e a interconexão - em uma lógica transnormativa - entre as esferas interna e internacional do fenômeno jurídico, de modo a transcender as concepções clássicas de relação entre elas. ${ }^{2}$

1 LAFER, Celso. A OMC e a regulamentação do comércio internacional: uma visão brasileira. Porto Alegre: Livraria do Advogado, 1998. p. 123-125; LAFER, Celso. O sistema de solução de controvérsias da Organização Mundial do Comércio. In: CASELLA, Paulo Borba; MERCADANTE, Araminta de (Coord.). Guerra comercial ou integração mundial pelo comércio?: a OMC e o Brasil. São Paulo: LTr, 1998. p. 729-755. p. 748.

2 Sobre o conceito de interconexão transnormativa, que leva em conta uma lógica transversal entre as ordens jurídicas interna e internacional, confira: MENEZES, Wagner. Ordem global e transnormatividade. Ijuí: Unijuí, 2005.
Esse rearranjo entre esferas de juridicidade anteriormente compreendidas de maneira individualizada e hermética, bem como modificações observadas na realidade internacional, tem demandado dos estudiosos do Direito Internacional esforços constantes de atualização e reinterpretação de seu objeto, que se desenrolam por meio de novos paradigmas conceituais aplicados às análises.

É nesse contexto que se insere o presente trabalho, que objetiva explorar o constitucionalismo e a comunitarização do Direito Internacional como perspectivas para o Direito Internacional, em especial no que se refere ao comércio internacional e ao seu pilar institucional central - a Organização Mundial do Comércio [OMC].

Isso ocorre, pois observa-se na realidade internacional, notadamente nas últimas décadas, os fenômenos de juridificação e de jurisdicionalização ${ }^{3}$ - que tem se manifestado, respectivamente, por meio da construção de normas e mecanismos jurídicos de regulamentação das relações entre os sujeitos e da instituição de Tribunais Internacionais, novas instâncias de aplicação e formulação do Direito Internacional na contemporaneidade. ${ }^{4} 5$

O comércio internacional, enquanto ramo profundamente influenciado pela força globalizante, se apresentou como terreno fértil ao desenvolvimento desses fenômenos. ${ }^{6}$ A constituição do sistema multilateral de comércio

3 Cumpre desde logo destacar, em breve comentário, que embora estejam conectados, os vocábulos "juridificação" e "jurisdicionalização" correspondem a fenômenos distintos. O vocábulo "juridificação" se conecta à noção de intensificação do elemento jurídico em dadas relações que antes estavam dominadas de elementos políticos, no que Celso Lafer identificou com a famosa expressão "adensamento de juridicidade" (vide nota de rodapé n. 2). O vocábulo “jurisdicionalização", por sua vez, corresponde à expansão do elemento de jurisdição no sistema jurídico internacional, ou seja, ao fato de que crescentemente as controvérsias são solucionadas por instâncias jurisdicionais - Cortes e Tribunais Internacionais. Esse segundo fenômeno tem sido claramente identificado por diversos autores, como por exemplo Antônio Augusto Cançado Trindade (vide nota de rodapé n. 5). As diferentes consequências e matizes teóricas de interpretação desses fenômenos serão melhor trabalhadas no decorrer deste trabalho e especialmente nas notas de rodapé. 4 TRINDADE, Antônio Augusto Cançado. International law for humankind: towards a new jus gentium (II). General course on public international law. Recueil des cours, v. 317, p. 9-312, 2005. Em especial, capítulo XXV, p. 183.

5 MENEZES, Wagner. A Jurisdicionalização do direito internacional: conflitos de competência entre tribunais internacionais, sua prevenção e resolução. 2011. 513 f. Tese (Doutorado) - Faculdade de Direito, Universidade de São Paulo, São Paulo, 2011. p. 150; MENEZES, Wagner. Tribunais Internacionais: jurisdição e competência. São Paulo: Saraiva, 2013.

6 Em relação à OMC, Elaini Cristina Gonzaga Silva utiliza em sua 
em suas origens e sua evolução é ilustração disso, sendo certo que a passagem do regime jurídico do General Agreement on Tariffs and Trade [GATT 1947] ${ }^{7}$ à OMC se deu em resposta às novas exigências e anseios da sociedade internacional, ${ }^{8}$ tais como as demandas por maior segurança jurídica e cooperação com fins ao desenvolvimento, como nortes ao comércio internacional. ${ }^{9}$

É exatamente essa busca intersubjetiva no Direito Internacional pela discussão, construção e efetivação de mecanismos que melhor equacionem os diferentes interesses do comércio internacional, bem como que instituam o respeito ao império do direito (rule of law) que está na base do multilateralismo econômico, que tem como arcabouço histórico o GATT 1947 e como moldura institucional a OMC. ${ }^{10} 11$

A OMC configura-se como principal organização internacional contemporânea responsável pela coordenação e desenvolvimento das relações comerciais internacionais, assumindo papel central no Direito Internacional Econômico, uma vez que funciona, simultaneamente, como instância supervisora das regras já acordadas e das obrigações assumidas pelos membros e como foro de contínua negociação destas e de novas regras. ${ }^{12} 1314$

dissertação de mestrado o termo "juridicização" com sentido aproximado, se referindo ao fenômeno "que conduz ao estabelecimento de um ordenamento jurídico por meio da introdução de normas secundárias e afirmação de normas primárias". SILVA, Elaini Cristina Gonzaga da. Juridicizaçãa das relações internacionais e solução de controvérsias: análise do sistema multilateral de comércio. 2007. 225 f. Dissertação (Mestrado em Direito) - Faculdade de Direito, Universidade de São Paulo, São Paulo, 2007. p. 29.

7 O GATT, sigla em inglês para Acordo Geral sobre Tarifas e Comércio foi um acordo instituído em 1947 inicialmente de maneira temporária, que deveria reger as relações entre as partes contratantes no lapso temporal até a entrada em vigor da Carta de Havana, que criava a Organização Internacional do Comércio. Com o fracasso na instituição da OIC, o GATT acabou exercendo suas funções, de maneira "permanente" e ampliada até a criação da OMC, em 1994.

8 AMARAL JÚNIOR, Alberto do. A Solução de controvérsias na OMC. São Paulo: Atlas, 2008. p. 97-100.

9 Para um histórico do GATT, e sobre suas limitações em garantir o desenvolvimento aos países "subdesenvolvidos", Cf: LAFER, Celso. O Gatt, a cláusula de nação mais favorecida e a América Latina. Boletim da Sociedade Brasileira de Direito Internacional, n. 55/60, p. 133 151, 1972-1974. p. 134-136.

10 JACKSON, Jonh H. The Jurisprudence of GATT and the WTO. Cambridge: Cambridge University Press, 2000. p. 8-9.

11 CARREAU, Dominique; JUILLARD, Patrick. Droit International Économique. Paris: Dalloz, 2007. p. 47-48.

12 THORSTENSEN, Vera. OMC-Organização Mundial do Comércio: as regras do comércio internacional e a nova rodada de negociações multilaterais. 2. ed. São Paulo: Aduaneiras, 2001. p. 27.

13 BARRAL, Welber. De Bretton Woods a Doha. In: BARRAL, Welber. (Org). O Brasil e a OMC. 2. ed. Curitiba: Juruá, 2006. p. 9-26. 14 SILVA, Roberto Luiz. Direito econômico internacional e direito comu-
No cerne do sistema multilateral de comércio, está o Sistema de Solução de Controvérsias da OMC, ${ }^{15}{ }^{16}$ que, embora possua arquitetura única, pelo aspecto especial de seus procedimentos e das relações entre as instâncias que o compõem, é sistema de natureza adjudicatória, de competência exclusiva face à ampla gama de temas sob guarida dos Acordos da Organização.

A centralidade que a OMC e seu Sistema de Solução de Controvérsias tem assumido na realidade internacional exige uma reflexão mais atenta sobre sua inserção no sistema jurídico internacional como um todo, no que consiste a principal justificativa para a análise dos paradigmas que possibilitam - de maneira diferenciada - essa inserção, objetivo central deste trabalho.

A pesquisa desenvolve-se por meio de uma abordagem diagnóstica e descritiva, que se preocupa em identificando a emergência das perspectivas de constitucionalismo e comunitarização a partir de fontes bibliográficas contrapostas aos fenômenos identificáveis na realidade internacional. Em seguida a essa breve introdução temático-metodológica, faz-se necessário o estudo panorâmico das mudanças de paradigma no Direito Internacional, rumo à ideia norteadora de uma comunidade internacional.

\section{As Mudanças de Paradigma do Direito INTERNACIONAL: RUMO A UMA COMUNIDADE INTERNACIONAL}

Esta seção busca analisar diferentes paradigmas do Direito Internacional, com o objetivo de reconhecer que o novo paradigma que se impõe na ordem jurídica internacional exige a participação das instituições internas, imiscuídas com os valores internacionais, em reafirmação da

nitário. Belo Horizonte: Del Rey, 1995. p. 103-104.

15 ORGANIZAÇÃO MUNDIAL DO COMÉRCIO. Acordo Constitutivo da Organização Mundial do Comércio. Disponível em: <http:// www.planalto.gov.br/ccivil_03/decreto/antigos/d1355.htm>. Acesso em: 10 fev. 2016; ORGANIZAÇÃO MUNDIAL DO COMÉRCIO. Entendimento relativo às normas e procedimentos sobre solução de controvérsias. Versão oficial em português segundo o decreto n. 1.355, de 30 dez. 1994, que promulga a Ata Final que Incorpora os Resultados da Rodada Uruguai de Negociações Comerciais Multilaterais do GATT. Disponível em: <http://www.planalto.gov.br/ccivil_03/ decreto/antigos/d1355.htm>. Acesso em: 10 fev. 2016.

16 BARRAL, Welber; PRAZERES, Tatiana. Solução de controvérsias. In: BARRAL, Welber. (Org). O Brasil e a OMC. 2. ed. Curitiba: Juruá, 2006. p. 27-46. 
consciência comunitária e dos interesses da coletividade internacional, além do desenvolvimento de uma interpretação sistêmica, integradora e constitucionalista.

Destaca-se, portanto, que não se pretende relatar um histórico do Direito Internacional - o que exigiria um espaço consideravelmente maior que esta seção assim como não foi esse o objetivo central dos autores citados. O intuito das páginas seguintes é explicitar a evolução do Direito Internacional de modo a evidenciar mudanças de paradigmas que ocorreram, e sustentar a compreensão da constitucionalização como o paradigma contemporâneo do Direito Internacional, para então tratar de suas consequências para a regulamentação do comércio internacional.

São recorrentes na literatura os diagnósticos de transformação da realidade internacional, bem como de sua próxima relação com mudanças profundas no Direito Internacional. Em uma ordem mundial em modificação, os Estados se tornam interconectados em uma rede de interdependências, e a esse quadro se adiciona como novidade a consciência dos povos sobre seu futuro comum, reconhecendo-se uns aos outros como parte da humanidade. ${ }^{17}$

Essas noções permanecem atuais, diante de mudanças que se aprofundaram nas últimas décadas, gerando efeitos não apenas nas relações internacionais, mas inclusive na estrutura do Direito Internacional.

Em seu curso geral de Direito Internacional da Academia de Direito Internacional de Haia, Christian Tomuschat trata da complexidade crescente da ordem jurídica internacional, como vetor de evolução do Direito Internacional e passagem de um paradigma a outro. $\mathrm{O}$ autor identifica quatro estágios nessa linha evolutiva: (a) em suas origens, o Direito Internacional como um direito de coexistência; (b) no segundo estágio, o Direito Internacional como um direito de cooperação; (c) no terceiro estágio, o Direito Internacional como um plano abrangente para a vida social; e (d) no quarto estágio, o Direito Internacional no bojo de uma comunidade internacional. ${ }^{18}$

17 ZACHER, Mark. The Decaying pillars of the Westphalian temple: Implications for International Order and Governance. In: ROSENAU, James; CZEMPIEAL, Ernst-Otto. Governance, Order and Change in World Politics. Cambridge: University Press, 1992. p. 58-101. 18 TOMUSCHAT, Christian. International law: ensuring the survival of mankind on the eve of a new century. General course on public international law. Recueil des cours, v. 281, p. 9-438, 1999. p. 56-90.
O autor parte dos estágios explicitados por Wolfgang Friedmann, ${ }^{19}$ que em seu estudo, chamava atenção para as transformações profundas na sociedade internacional, principalmente desde a criação da Carta das Nações Unidas, que teriam engendrado a passagem de um direito de coexistência entre os Estados, para um paradigma de cooperação mais amplo.

Nessa análise, o estágio de coexistência descreve o Direito Internacional como um direito limitado a governar as relações entre os Estados, e consequentemente concebido como necessário apenas para limitados propósitos. Reinava, pois, a distinção firme de ratione materiae entre o Direito Internacional e o direito interno dos Estados, sendo que o primeiro tinha como funções essenciais a delimitação de competências estatais, a partir da territorialidade, e a preservação da existência e independência dos Estados. ${ }^{20}$

No segundo estágio, a era de cooperação se inaugurava com o fim da primeira guerra mundial e a criação da Liga das Nações, cujo objetivo primário era promover a cooperação, com fins de alcançar a paz e segurança internacionais. A criação de uma estrutura institucional de âmbito global, acompanhada de um aparato normativo, era o primeiro passo na superação da clássica teoria da igualdade soberana.

Inaugurado, então, o impulso de cooperação entre os Estados com o objetivo de lidar com os desafios em comum enfrentados pela humanidade, expandiu-se pelas mais diversas áreas à medida que novos desafios de natureza transnacional eram descobertos, o que resultou na institucionalização e fortalecimento do Direito Internacional como meio de alcançar objetivos maiores da humanidade. Nesse estágio, marcado pela criação e evolução do "Sistema ONU", se desenvolveu a ideia de que certos temas - não somente ligados à paz e segurança internacionais, mas também o desenvolvimento econômico, a autodeterminação dos povos, os refugiados e os recursos ambientais - são de responsabilidade coletiva da comunidade internacional. ${ }^{21}$

Assim, o desenvolvimento progressivo do Direito

19 FRIEDMANN, Wolfgang. The Changing Structure of International Law. New York: Columbia University Press, 1964.

20 TOMUSCHAT, Christian. International law: ensuring the survival of mankind on the eve of a new century. General course on public international law. Recueil des cours, v. 281, p. 9-438, 1999. p. 56-59.

21 TOMUSCHAT, Christian. International law: ensuring the survival of mankind on the eve of a new century. General course on public international law. Recueil des cours, v. 281, p. 9-438, 1999. p. 59-63. 
Internacional o levou a uma nova etapa, marcada pela significativa diminuição do espaço de soberania dos Estados, vez que ligados a uma rede crescente de compromissos jurídicos em áreas como os direitos humanos, a democracia nos governos internos e metas de bem-estar dos indivíduos e de boa governança. Nesse sentido, conforme a interdependência entre os Estados se intensifica e os compromissos que afetam a vida dos cidadãos se adensam, os Estados são vinculados profundamente por essas obrigações.

Há, desse modo, um rearranjo do Direito Internacional, que passa, de um conjunto de regras que guiavam os Estados em suas relações entre si, a significar um corpus juris multifacetado que permeia todos os aspectos da vida humana. Esse desenvolvimento observado na terceira fase, contudo, se deu através de diferentes instrumentos, com papel destacado da soft law, que tende, paulatinamente, a se "endurecer". 22

Merece destaque o fato de que os novos compromissos assumidos pelo Direito Internacional são cada vez mais complexos, exigindo uma lógica diferente de implementação, que significa, pois, uma tradução dessas regras para a normatividade interna, pelos poderes estatais, de modo a gerar a produção de seus efeitos nas relações verticais, horizontais e transnacionais.

Tomuschat parece, então, sugerir um quarto paradigma, de certo modo em complementação ao terceiro paradigma, que estaria ainda em desenvolvimento às vésperas da virada do milênio. Esse paradigma, do Direito Internacional para a comunidade internacional, se caracteriza pela hierarquização de valores na ordem jurídica internacional, pela proteção dos interesses comunitários e pela institucionalização de instrumentos coletivos protetivos, significando, portanto, a tradução normativa do conceito de comunidade internacional. ${ }^{23}$

De maneira correlata, Bruno Simma enuncia a evolução do Direito Internacional clássico para o contemporâneo como a passagem de um sistema jurídico de caráter bilateral para uma perspectiva focada no interes-

22 TOMUSCHAT, Christian. International law: ensuring the survival of mankind on the eve of a new century. General course on public international law. Recueil des cours, v. 281, p. 9-438, 1999. p. 63-72. 23 Nas palavras do autor: "[...] it would be wrong to assume that States as a mere juxtaposition of individual units constitute the international community. Rather, the concept denotes an overarching system which embodies a common interest of all States and, indirectly, of mankind." TOMUSCHAT, Christian. Obligations Arising for States without or against Their Will. Recueil des cours, v. 241, p. 195-374, 1993. p. 227. se comunitário. ${ }^{24}$ Assim, estaria em curso uma evolução da compreensão do sistema jurídico internacional, distanciando-se de uma lógica de direitos e obrigações correlativas entre os Estados, e aproximando-se da consciência de interesses da comunidade internacional. ${ }^{25}$

Essa evolução tem levado a uma crescente institucionalização e organização da sociedade internacional, como resultado da necessidade de encontrar novas soluções para os novos problemas. Tal amadurecimento da ordem jurídica internacional promove profundas transformações na natureza do Direito Internacional e urge por mecanismos de participação dos diferentes sujeitos, nesse contexto de "comunitarização" e "publicização" das relações jurídicas internacionais. ${ }^{26}$

$\mathrm{O}$ autor destaca diversas facetas da realidade internacional que o levaram a reconhecer que o surgimento da consciência desses interesses comunitários não provocou uma completa inversão da lógica das relações internacionais, havendo uma coexistência e interação entre ambos os paradigmas no sistema jurídico internacional. ${ }^{27}$

24 O interesse comunitário se coloca como antítese ao conceito de bilateralismo: "The antithesis of the bilateralism thus described consists of the assertion of community interest in the development of international law in a different direction, as it were. A first, very tentative, definition of "community interest" could perceive it as a consensus according to which respect for certain fundamental values is not to be left to the free disposition of States individually or inter se but is recognized and sanctioned by international law as a matter of concern to all States". SIMMA, Bruno. From bilateralism to community interest in international law. Recueil des cours, v. 250, p. 217-384, 1994. p. 233.

25 Para uma visão distinta do estágio atual de evolução do Direito Internacional, Cf: "Thus, the change from a State-centric international society to a global community with radically reduced significance of States will probably take far more time than is expected by those who have advocated the decline or retreat of States, or the high cause of global market economy or global civil society. The fundamentally State- centric character of the international or global society will likely persist in the twenty-first century. The sovereign States system, whose fundamental principle is the mutual recognition of the supremacy of territorial sovereignty of States in managing human affairs, will remain as the most important organizational and managing principle of the entire bumanity in the world." YASUAKI, Onuma. A Transcivilizational Perspective on International Law. Questioning Prevalent Cognitive Frameworks in the Emerging Multi-Polar and Multi-Civilizational World of the TwentyFirst Century. Recueil des cours, v. 342, p. 77-418, 2010. p. 101-102. 26 Bruno Simma menciona a "comunitarização" e "publicização" das relações jurídicas internacionais como aspectos ligados à construção de uma consiência global, o que pode ser demonstrado por exemplo por meio da crescent precupação internacional com direitos humanos, meio ambiente e interdependência econômica. As relações internacionais passam a respeitar lógicas para além da interação intergovernamental clássica. SIMMA, Bruno. From bilateralism to community interest in international law. Recueil des cours, v. 250, p. 217-384, 1994. p. 234

27 SIMMA, Bruno. From bilateralism to community interest in international law. Recueil des cours, v. 250, p. 217-384, 1994. p. 248. 
2829 A ideia de comunidade internacional, contudo, desempenha relevante função ideológica, ao destacar que as regras construídas e as decisões tomadas pelos agentes estatais impactam na vida de seres humanos, devendo-se, ainda, buscar a construção de capacidade normativa-institucional para a concretização dessa noção. ${ }^{30} 31$

Na busca pelo paradigma "pós-moderno" do sistema internacional, ao proclamar pelos fundamentos do Direito Internacional pós-moderno, Paulo Borba Casella explicita que este seria o embasamento para uma "ordenação teleologicamente humana do mundo". ${ }^{32}$ Assim, o autor indica:

Terminados os dias da concepção estatizante e uniformizadora do Direito Internacional, que se pautava pelas normas de coexistência entre os Estados e somente entre eles se reconhecia a condição de sujeito, para ver instalado o direito internacional pós-moderno: dividido entre o anseio de construção da cooperação, com alguns laivos de implementação de patamar tendente à integração, em contextos específicos, de coesão econômica e de compartilhamento de valores, que permita superar algumas das dicotomias mais gritantes do direito internacional, como a sobrevivência da pretensão da exclusividade dos papéis estatais, no plano do direito e

28 Também, nesse sentido, Cf: "The constitutional system set up for the international community in the United Nations Charter is of course far from being perfect. It has only a limited capacity to enforce compliance with its basic rules. This, however, should not detract our attention from the fact that we live in an international legal system rather different from the one existing before 1945."FROWEIN, Jochen A. Reactions by Not Directly Affected States to Breaches of Public International Law. Recueil des cours, v. 248, p. 349-445, 1994. p. 358. 29 No mesmo sentido, Cf: " [... the legal protection of international community interests was the result of a gradual and, at first, almost imperceptible general trend. [...] Yet another interesting feature of this phenomenon is that the protection of community interests in international law has been effected through the adaptation, not the abandonment, of existing legal regimes. The new concepts, while being revolutionary in their substance, have been formulated in such a way as to fit into well-known legal frameworks." VILLALPANDO, Santiago. The Legal Dimension of the International Community: How Community Interests Are Protected in International Law? European Journal of International Law, v. 21, n. 2, p. 387-419, 2010. p. 407-409.

30 SIMMA, Bruno. From bilateralism to community interest in international law. Recueil des cours, v. 250, p. 217-384, 1994. p. 248.

31 Também em sentido correlato, Pierre Marie Dupuy identifica a comunidade internacional como "ficção jurídica" e como "imperativo categórico", funções da noção na ordem jurídica internacional: "La fiction juridique de la «communauté internationale» est le moyen technique de promotion de la visée philosophique de diplomates et d'hommes politiques qui font souvent du Kant [...]”.Cf: DUPUY, Pierre-Marie. L'unité de l'ordre juridique international: cours général de droit international public. Recueil des cours, v. 297, p. 9-489, 2002. p. 267.

32 CASELLA, Paulo Borba. Direito internacional pós-moderno e a revisão dos modelos institucional e normativo. In: CASELLA, Paulo Borba. BRIC- Brasil, Rússia, Índia, China e África do Sul: uma perspectiva de cooperação internacional. São Paulo: Atlas, 2011. p. 113-137. p. 121. das relações internacionais, quando mais e mais se veem a emergência e a atuação dos agentes não estatais. ${ }^{33}$

Observa-se, portanto, o momento de transição pelo qual passa o Direito Internacional. ${ }^{34} \mathrm{~A}$ medida em que se torna mais complexo, o Direito Internacional se institucionaliza e se hierarquiza, provocando também uma hibridização com o direito interno, além de uma tendência a abarcar o ser humano como seu sujeito central. O paradigma contemporâneo da sociedade internacional exige, pois, uma nova formulação do gerenciamento dos conflitos, de modo a integrar os diferentes setores do Estado em respeito ao "international rule of law". 35

A organização do Direito Internacional a partir da centralização do indivíduo exige que o Direito Internacional seja traduzido em estruturas, instituições e mecanismos também internos, de modo a abarcar níveis de normatividade e governança que alcancem o cidadão. Esse quadro demanda, assim, uma reestruturação da ordem jurídica internacional para além dos Estados e também em face dos indivíduos, e por isso se destaca a relevância do paradigma constitucionalista do Direito Internacional, como se passa a observar a seguir.

\section{O Paradigma Constitucionalista do Direito InTERnacional}

Embora a concepção de constituição no Direito Internacional não seja recente, ${ }^{36}$ a sua aplicação tem sido

33 CASELLA, Paulo Borba. Direito internacional pós-moderno e a revisão dos modelos institucional e normativo. In: CASELLA, Paulo Borba. BRIC-Brasil, Rússia, Índia, China e África do Sul: uma perspectiva de cooperação internacional. São Paulo: Atlas, 2011. p. 113-137. p. 120. 34 Assim postula o autor: "ante as mutaçoes verificadas na nova realidade, é preciso alcançar nova regulação internacional. De fundamentos mais amplos, para assegurar os resultados adequados dessa construção do direito internacional pósmoderno". CASELLA, Paulo Borba. Direito internacional pós-moderno e a revisão dos modelos institucional e normativo. In: CASELLA, Paulo Borba. BRIC- Brasil, Rússia, Índia, China e África do Sul: uma perspectiva de cooperação internacional. São Paulo: Atlas, 2011. p. 113-137. p. 126.

35 Em outro texto, Paulo Borba Casella reforça essa necessidade: CASELLA, Paulo Borba. Fundamentos e perspectivas do direito internacional pós-moderno. Revista da Faculdade de Direito da Universidade de São Paulo, São Paulo, p. 433-466, jan./dez. 2006. p. 441.

36 Segundo Bruno Simma, a primeira aplicação do termo ao Direito Internacional foi feita em 1926, por Alfred Verdross, na obra "Die Verfassung der Völkerrechtsgemeinschaft' (VERDROSS, Alfred. Die Verfassung der Völkerrechtsgemeinschaft, Vienna and Berlin, Springer, 1926.): "According to Verdross, the term "constitution" denotes the norms which regulate the basic order of a community, that is, its structure, organization and allocation of competences. For Verdross, writing in 1926, the existence of a universal 
desenvolvida pela doutrina nas últimas décadas, como um paradigma de substituição à ordem internacional estatocêntrica, e em contraposição à corrente fragmentária, revisitando, assim, a unidade e a coerência como pilares do sistema jurídico internacional. ${ }^{37}$

Desde os primórdios do uso do termo ao Direito Internacional, o vocábulo vem associado a diversos sentidos correlatos, tais como: (i) as normas basilares que regulam a relação entre os sujeitos na ordem internacional universal; 38 (ii) os princípios fundamentais de caráter costumeiro responsáveis pela determinação de competências e funções na comunidade internacional; ${ }^{40}$ (iii)

international law grounded in and held together by the basic norm of pacta sunt servanda justified the use of the term "constitution", even in absence of a written document." SIMMA, Bruno. From bilateralism to community interest in international law. Recueil des cours, v. 250, p. 217-384, 1994. p. 260.

37 Nessa perspectiva de oposição ao paradigma fragmentário, Cf: VAN AAKEN, Anne. Defragmentation of Public International Law Through Interpretation: A Methodological Proposal. Indiana Journal of Global Legal Studies, v. 16, p. 483-512, 2009. COHEN, Harlan Grant. From Fragmentation to Constitutionalization. Pacific McGeorge Center for Global Business and Development Law Journal, v. 25, p. 381-394, 2012.

38 Conforme a visão de Alfred Verdross: 'La conception universaliste de la superordination du droit des gens se trowve aussi dans la doctrine et la pratique anglosaxonne de ces temps; c'est l'ancien sens de l'adage bien connu « international law is a part of common law. „ Car le sens original de cette formule est tel que le droit des gens doit etre applique, meme s'il est en contratradiction avec le droit national, parce que le droit international forme la constitution mondiale de laquelle dependent tous les Etats civilisesi." (grifo nosso). VERDROSS, Alfred. Le fondement du droit international. Recueil des cours, v. 16, p. 247-323, 1927. p. 314.

39 De modo correlate, o Christian Tomuschat explicita: "Given the developments triggered by the UN Charter, today a community model of international society would seem to come closer to reality than any time before in bistory. According to this interpretation, States live, as from their birth, within a legal framework of a limited number of basic rules which determines their basic rights and obligations with or without their will, leaving them, however, sufficient room for self-responsible action within the openings of that legal edifice. One may call this framework, from which every State receives its legal entitlement to be respected as a sovereign entity, the constitution of international society or, preferably, the constitution of the international community, community being a term suitable to indicate a closer union than between members of a society." TOMUSCHAT, Christian. Obligations Arising for States without or against Their Will. Recueil des cours, v. 241, p. 195-374, 1993. p. 210-11. 40 Scelle intitula a segunda parte de seu curso como "Technique Constitutionnelle du Droit des Gens", na qual afirma: "Au stade interétatique, au contraire, les principes constitutionnels demeurent à l'état de coutume, même si l'on peut en rencontrer l'expression dans des textes conventionnels: le traité joue en ce cas le rôle d'un élément coutumier. Il n'y a qu'une chose qui soit impossible, c'est l'absence de règles constitutives ou constitution-nelles. L'instinct seul des sujets de droit, membres de la Société internationale, suffit à les déterminer, car le senti- ment de la nécessité entraîne l'obéissance commune à la règle qui en découle implicitement. [...] Contenu du droit constitutionnnel international. - Que contient cet ensemble normatif? D'abord et nécessairement une détermination des compétences des sujets de droit, notamment des gouvernants. [...]" SCELLE, Georges. Règles générales du droit de la paix. Recueil des cours, v. 46, p. 327-703, 1933. p. 422. a limitação à soberania dos Estados na ordem jurídica internacional; ${ }^{41}$ (iv) a estrutura normativa-institucional de um "Estado mundial"; ${ }^{42}$ e (v) a cogência de instrumentos e estruturas formais como a Carta das Nações Unidas. ${ }^{43} 44$

41 Nas palavras do autor: "[...] Nevertheless, the developments which have taken place during the past half-century in the organisation and composition of the international community and in the law regarding the use of force, have made a substantial impact upon the constitutional foundations of the international legal order. Whether international law can now properly be regarded as "law with a constitution" may be controversial, for text-books still for the most part tend to treat international organisation as a super-structure upon international law rather than as the constitutional framework of the international community. [...] True, general international law has not yet been properly integrated within this constitutional framework, and much progress has yet to be made before we can speak with confidence of international law having a constitution. But the constitutional framework of international law provided by international organisation is now so important that in the opinion of the present writer it must be given a prominent place in any analysis of the general principles of international law." WALDOCK, Humphrey. General course on public international law. Recueil des cours, v. 106, p. 1-251, 1962. p. 7-8.

42 " [...] The task [the draftsmen of an International Bill of Rights] is no less than one of the international codification, in both its consolidating and its legislative sense, or the major constitutional law of mankind - a sphere in which the science of jurisprudence and politics converge in a most acute form." LAUTERPACHT, Hersch. The international protection of human rights. Recueil des cours, v. 70, p. 1-108, 1947. p. 89-90. “[...]S'ils sont des juristes, ils n'ont pas besoin d'attacher une importance excessive à l'argument banal qu'une fédération mondiale mettrait fin au droit international, en le transformant en droit constitutionnel de l'Etat mondial. Il n'en serait pas nécessairement ainsi: le changement qui en résulterait serait surtout une question de terminologie. En tout cas, si le résultat est souhaitable à d'au- tres points de vue, la disparition formelle de la science du droit international est indifférente." LAUTERPACHT, Hersch. Règles générales du droit de la paix. Recueil des cours, v. 62, p. 95-422, 1937. p. 411.

43 Na visão de Georg Schwarzenberger: "In an international community in the strict sociological meaning of the term, the overriding character of the interests of the whole - the constitutional law of the community-would be self-understood, and suitable reservations of international public policy in individual treaties could be taken for granted. Within the framework of a world society organised on the confederate pattern in the United Nations and its Specialised Agencies, the priority of the "higher" law of these international quasi-orders is less absolute. The matter is regulated by the rules of international law governing the conflict of treaties". SCHWARZENBERGER, Georg. The principles and standards of international economic law. Recueil des cours, v. 117, p. 1-98, 1966. p. 47. "[...] the 'constitution of the organized community of $\mathrm{Na}$ tions' within the framework of the United Nations, another attempt on the same pattern of a world confederation, must still be treated as being sub judice.” SCHWARZENBERGER, Georg. The fundamental principles of international law. Recueil des cours, v. 87, p. 191385, 1955. p. 207.

44 Em perspectiva semelhante: "Why may we speak of a constitutional structure? While international law developed as a system of co-ordination among States based on the sovereign will of those 
Embora com diferentes nuances capturadas por cada autor, a perspectiva traz implícita a crença no Direito Internacional como um instrumento universalizante de transformação positiva da realidade internacional e de concretização de valores e interesses comunitários.

Mesmo diante da dificuldade de conceituação de vocábulos como "constituição", "constitucionalizạ̧ãa”" " constitucionalismo" em suas acepções ligadas ao fenômeno jurídico internacional, dada a multiplicidade de autores que oferecem conceitos próprios, ainda que muitas vezes sobrepostos, se torna necessário buscar precisar esses termos, no seu uso por parte de alguns doutrinadores.

Uma das estudiosas no tema na contemporaneidade, Anne Peters, entende que o "constitucionalismo global" é uma agenda que busca a aplicação de princípios constitucionais na esfera jurídica e a "constitucionalizaçãa" consistiria na emergência de aspectos constitucionais no Direito Internacional, como instrumento hermenêutico e como via de reforçar sua legitimidade, efetividade e justiça. ${ }^{45}$

Juntamente com Klaus Armigeon, a autora afirma, em outra oportunidade, que se poderia denominar "constituição internacional" o núcleo das normas mais importantes que regulam a atividade política na comunidade global. Entretanto, os autores preferem a expressão "Direito constitucional global", por entenderem que o termo "constituição" poderia trazer concepções ligadas ao fenômeno jurídico interno, não sendo adequada uma simples "tradução" do conceito no direito interno para o Direito internacional. ${ }^{46}$

Assim, não se trata simplesmente de transpassar o conceito de "constituição" à uma escala superior, é necessário estudar o fenômeno em suas características próprias no ambiente global, em suas dimensões descritiva

agreeing on a treaty or forming a rule of customary international law, the Security Council now has the mandate to decide against the will of the State concerned, at least as long as that State remains a Member of the United Nations. [...] However, even for countries who have not become Members, and there are very few indeed, the constitution of the world community which we find enshrined in the United Nations Charter is not without considerable importance." FROWEIN, Jochen A. Reactions by Not Directly Affected States to Breaches of Public International Law. Recueil des cours, v. 248, p. 349-445, 1994. p. 356.

45 PETERS, Anne. The merits of global Constitutionalism. Indiana Journal of Global Legal Studies, v. 16, p. 397-411, 2009. p. 397.

46 PETERS, Anne; ARMINGEON, Klaus. Introduction-Global Constitutionalism from an Interdisciplinary Perspective. Indiana Journal of Global Legal Studies, v. 16, p. 385-395, 2009. p. 387. e prescritiva. ${ }^{47}{ }^{48}$ Nesse quadro teórico, "constitucionalização" indicaria a emergência de aspectos constitucionais na ordem jurídica internacional, sendo um processo que engendra um "reforço de normatividade" na ordem global. ${ }^{49}$

Luigi Ferrajolli, por sua vez, conecta o conceito de "constitucionalismo" no Direito Internacional à implementação do império do direito na ordem jurídica internacional, como um sistema hierárquico de normas e princípios axiológicos, reconhecendo uma conexão direta com a noção de tottus orbis empregada por Francisco de Victoria. ${ }^{50} 51$

Uma definição similar é dada por Pierre-Marie Dupuy, englobando uma dimensão material, como um conjunto de princípios jurídicos de importância primária para a sociedade internacional, e uma dimensão institucional, através da designação de órgãos e definição de suas competências. ${ }^{52}$

47 Conforme explicitam os autores em outro trecho: "We employ the term 'global constitutionalism' in order to characterize an academic and political agenda which identifies and advocates the application of constitutionalist principles, such as the rule of law, checks and balances, human rights protection, and possibly democracy, in the international legal sphere in order to improve the effectiveness and the fairness of the international legal order. Therefore, global constitutionalism has both descriptive and prescriptive elements. It does not merely claim to describe some features of the status quo of international relations, but also seeks to provide arguments for their further development in a specific direction." PETERS, Anne; ARMINGEON, Klaus. IntroductionGlobal Constitutionalism from an Interdisciplinary Perspective. Indiana Journal of Global Legal Studies, v. 16, p. 385-395, 2009. p. 389.

48 Como exemplo de uma visão contrária, que parte da constituição interna (norte-americana) para reconhecê-la em organizações constitucionais, Cf: McGINNIS, John O.; MOVSESIAN, Mark L. The World Trade Constitution. Harvard Law Review, v. 114, issue 2, p. 511-605, Dec. 2000.

49 Assim, constitucionalização global significaria: "[...] a catchword for the continuing, but not linear, process of the gradual emergence and deliberate creation of constitutionalist elements in the international legal order by political and judicial actors, bolstered by an academic discourse in which these elements are identified and further developed." PETERS, Anne; ARMINGEON, Klaus. Introduction-Global Constitutionalism from an Interdisciplinary Perspective. Indiana Journal of Global Legal Studies, v. 16, p. 385-395, 2009. p. 389-90.

50 FERRAJOLI, Luigi. A soberania no mundo moderno: nascimento e crise do Estado nacional. São Paulo: M. Fontes, 2002. p. 53.

51 Para uma análise mais detalhada do conceito de totus orbis em Francisco de Vitória, Cf: RANGEL, Vicente Marotta. Francisco de Vitoria y el Federalismo Internacional. In: MANGAS MARTÍN, Araceli. La Escuela de Salamanca y el Derecho Internacional en America: del Passado al Futuro. Salamanca: Asociacion Espanola de Professores de Derecho Internacional, 1993. p. 205-214. CAPUCIO, Camilla. Apontamentos sobre Francisco de Vitória e Francisco Suarez: construção doutrinária e fundamento do jus gentium. In: MENEZES, Wagner. (Org.). Direito internacional clássico e seu fundamento. Belo Horizonte: Arraes Editores, 2014. p. 62-74.

52 DUPUY, Pierre-Marie. The Constitutional Dimension of the 
Percebe-se, portanto, que o uso restrito da palavra "constituição" reservado unicamente ao soberanismo estatal, que não encontraria poder superior, não reflete a realidade atual. Nesse sentido, também John Jackson adota um conceito amplo de "constituição", de modo a também abarcar o fenômeno jurídico internacional. ${ }^{53}$

O termo "constitucionalismo", em sua concepção, se aplica a diversos níveis de governança, e o autor identifica quatro usos diversos para o termo: (i) aplicado ao Estado-nação que possui uma constituição formal; (ii) relativo ao conteúdo material normativo, ligado à proteção dos direitos humanos e à democracia, (iii) usado para descrever o desenvolvimento de uma organização internacional ou transnacional; e (iv) aplicado para descrever o processo evolutivo de criação e aplicação de normas relativas ao sistema do Direito Internacional como um todo, de modo a desafiar o seu caráter soberanista. ${ }^{54}$ Esse quarto sentido, que o autor busca desenvolver, tem grande relevância para o sistema jurídico internacional, e se aplica à busca por novos fundamentos do Direito Internacional. ${ }^{55}$

Desse modo, "constitucionalismo" é uma perspectiva que, se desenvolvida com a devida reflexão, discussão e diálogo com a prática, poderia substituir as noções problemáticas de soberania e consenso na formação do Direito Internacional por outros fundamentos, constituídos como alicerces de um novo paradigma. ${ }^{56}$ Além

Charter of the United Nations Revisited. Max Planck Yearbook of United Nations Law, v. 1, p. 1-32, 1997. p. 3.

53 E, assim, Jackson usa a expressão "[... to to embrace a variety of "constitution" authorities, using a variety (and often a large number) of instruments and traditional practices and experiences which have some impact on the views of constituents of an entity concerning the permissible procedures and behaviors involved in the process of governing. "JACKSON, John. Sovereignty, the WTO and Changing Fundamentals of International Law. New York: Cambridge University Press, 2006. p. 222.

54 JACKSON, John. Sovereignty, the WTO and Changing Fundamentals of International Law. New York: Cambridge University Press, 2006. p. 223-224.

55 Assim explicita: "As to the fourth definition type mentioned above, the term could signify and endorse an overall approach to "redesigning" the fundamentals of international law (including international economic law and international institutional law). It could be the rubric with a flavor of approval and promise, to cover present and further necessary study and activity designed to examine the "gestalt" of the international legal system. "Constitutionalism" thus may be a good approach to developing replacements or substitutes for the many existing perplexities and challenges to the overall international system." JACKSON, John. Sovereignty, the WTO and Changing Fundamentals of International Law. New York: Cambridge University Press, 2006. p. 224.

56 JACKSON, John. Sovereignty, the WTO and Changing Fundamentals of International Law. New York: Cambridge University Press, 2006. disso, essa perspectiva reforça a necessidade de desenvolver parâmetros de legitimidade, democracia, transparência e accountability ao Direito Internacional e às instituições internacionais. ${ }^{57} 58$

Uma vez visitados os principais alicerces conceituais do paradigma constitucionalista do Direito Internacional e de sua relação com a ideia de comunidade e de "comunitarização", cumpre às próximas seções o desafio de discutir a aplicabilidade conceitual dessas noções ao sistema multilateral de comércio.

\section{Constitucionalismo e Comunitarização NA OMC: ENTRE ABORDAGENS TEÓRICAS E POSSIBILIDADES REAIS}

A perspectiva do constitucionalismo é uma concepção mais recentemente aplicada por parte da doutrina à OMC, embora persista a natural diferença de significações a essa atribuição conceitual. ${ }^{59}$

Segundo diagnóstico de Jeffrey Dunoff, a maior parte dos autores aplica essa noção no contexto do sistema multilateral de comércio para se referir: (a) à arquitetura institucional da OMC; (b) ao processo de mediação judicial entre valores conflitantes; e (c) à primazia de um conjunto de compromissos normativos. ${ }^{60}$

p. 224-225.

57 JACKSON, John. Sovereignty, the WTO and Changing Fundamentals of International Law. New York: Cambridge University Press, 2006. p. 227.

58 Para discussões sobre accountability relacionada à OMC, e sobre os desafios para mensurá-la, embora em um arcabouço teórico distinto, Cf: FIGUEIREDO, Celso Henrique Cadete de. A promoção de accountability na Organização Mundial do Comércio: uma análise horizontal e vertical. Revista de Direito Internacional, Brasília, v. 11, n. 2, p. 279-309, 2014.

59 TRACHTMAN, Joel P. The Constitutions of the WTO. European Journal of International Law, v. 17, n. 3, p. 623-646, 2006.

60 O autor faz um diagnóstico dos principais sentidos conferidos ao constitucionalismo à $\mathrm{OMC}$, embora tenha perspectiva crítica e contrária à de aplicação do constitucionalismo à OMC, Cf: "International legal scholarship, particularly trade scholarship, is preoccupied with questions of constitutionalism. However, neither WTO texts nor practice suggest that the WTO is a constitutional entity. The disjunction between scholarship and practice is puzzling: Why would scholars debate the WTO's (non-existent) constitutional features? [... ]” DUNOFF, Jeffrey L. Constitutional Conceits: The WTO's 'Constitution' and the Discipline of International Law. European Journal of International Law, v. 17, n. 3, p. 647-675, 2006. p. 647. DUNOFF, Jeffrey L. Why Constitutionalism Now? Text, Context and the Historical Contingency of Ideas. Journal of International Law and International Relations, v. 1, p. 191-211, 2004-2005. 
Inserido na aplicação do conceito à arquitetura institucional na OMC, John Jackson descreve a passagem da abordagem "power-oriented", em direção à abordagem "rule-oriented", ${ }^{61}$ fenômeno ao qual nos referimos anteriormente, que Celso Lafer denominou de "adensamento de juridicidade", e foi materializado com a passagem do GATT 1947 à OMC.

A segunda e dominante corrente destaca o sistema de solução de controvérsias da OMC como o motor de seu constitucionalismo e, nesse sentido, Deborah Cass afirma que o Órgão de Apelação da OMC "é a força dinâmica por trás da construção constitucional em virtude da sua capacidade de geração de normas e estruturas constitucionais durante a resolução de disputas.” 626364

Inserido na última corrente, Ernst-Ulrich Petersmann reconhece no constitucionalismo a eleição de valores normativos primários e hierarquizados, que cons-

61 Embora sempre tenha reforçado a relevância dessa passagem, nota-se certa uma evolução na concepção de "constitucionalismo" ligado à $\mathrm{OMC}$ pelo autor, no decorrer das seguintes obras: JACKSON, Jonh H. The Jurisprudence of GATT and the WTO. Cambridge: Cambridge University Press, 2000. JACKSON, John H. The World Trade Organization: Constitution and Jurisprudence. London: Royal Institute of International Affairs, 1998. JACKSON, John H. The WTO "Constitution" and Proposed Reform: Seven "Mantras" Revisited. Journal of International Economic Law, v. 4, p. 67-78, 2001. JACKSON, John H. The Great 1994 Sovereignty Debate: United States Acceptance and Implementation of the Uruguay Round Results. Columbia Journal of Transnational Law, v. 36, p. 157-188, 1998. JACKSON, John. Sovereignty, the WTO and Changing Fundamentals of International Law. New York: Cambridge University Press, 2006.

62 Tradução livre do original em língua inglesa: "is the dynamic force behind constitution building by virtue of its capacity to generate constitutional norms and structures during dispute resolution." CASS, Deborah Z. The "Constitutionalization" of International Trade Law: Judicial Norm-Generation as the Engine of Constitutional Development in International Trade'. European Journal of International Law, v. 12, p. 39-75, 2001. p. 42.

63 ORGANIZAÇÃO MUNDIAL DO COMÉRCIO. Acordos e documentos. Disponível em: <www.wto.org>. Acesso em: 10 fev. 2016.

ORGANIZAÇÃO MUNDIAL DO COMÉRCIO. Legal Affairs Division. WTO analytical index: Guide to WTO Law and Practice. Disponível em: <http://www.wto.org/english/res_e/ booksp_e/analytic_index_e/analytic_index_e.htm >. Acesso em: 10 fev. 2016.

64 Em uma posição contrária, Leonor Clodovil nega a existência de referido fenômeno: "A OMC é um sistema basicamente contratual e intergovernamental, que não tem natureza constitucional em nenhum sentido. O papel dos julgadores na OMC é contratual, diferentemente do papel atribuído a um juiz nacional pela constituição, consistindo em um exame mecânico sobre a concordância da ação do Membro com as obrigações que ele assumiu." CLODOVIL, Leonor Augusta Giovine. O interesse público no Antidumping. 2009. 345 f. Tese (Doutorado em Direito) - Faculdade de Direito, Universidade de São Paulo, São Paulo, 2009. p. 295. tituem e limitam o poder dos governos e os direitos dos cidadãos. Em um sentido mais profundo, a constitucionalização da OMC envolve a sua submissão aos direitos humanos fundamentais e aos princípios de justiça internacional. ${ }^{65}$

$\mathrm{Na}$ realidade, em sua obra é possível identificar o constitucionalismo na OMC como fenômeno que engloba também os dois sentidos citados, ligados à concretização do rule of law por meio do Sistema de Solução de Controvérsias. ${ }^{66}$ Contudo, o autor vai além dos sentidos mencionados, ao reconhecer expressamente a correlação entre o sistema multilateral de comércio e a realização de valores ligados aos direitos humanos. ${ }^{67}$

65 Ernst-Ulrich Petersmann possui uma farta produção bibliográfica nessa temática. Embora outros artigos também se remetam a essas noções, destacam-se alguns dos trabalhos do autor que exploram essa relação: PETERSMANN, Ernst-Ulrich. How to Constitutionalize International Law and Foreign Policy for the Benefit of Civil Society? Michigan Journal of International Law, v. 20, p. 1-30, 1998. p. 13. PETERSMANN, Ernst-Ulrich. Human Rights, International Economic Law and Constitutional Justice: A Rejoinder. European Journal of International Law, v. 19, issue 5, p. 955-960, 2008. PETERSMANN, Ernst-Ulrich. Multilevel Judicial Governance as Guardian of the Constitutional Unity of International Economic Law. Loyola of Los Angeles International and Comparative Law Review, v. 30, issue 3, p. 367-418, 2008. PETERSMANN, Ernst-Ulrich. The WTO Constitution and Human Rights. Journal of International Economic Law, v. 3, p. 19-25, 2000. PETERSMANN, Ernst-Ulrich. Legal, Economic and Political Objectives of National and International Competition Policies: Constitutional Functions of WTO "Linking Principles" for Trade and Competition. New England Law Review, v. 34, p. 145-162, 1999.

66 Nesse sentido: "Since the establishment of a GATT Legal Office in 1983, the progressive transformation of the multilevel GATT dispute settlement system into a compulsory worldwide jurisdiction for the settlement of trade disputes through panel, appellate, arbitration, and domestic judicial procedures continues to promote constitutional 'checks and balances' between the political and judicial branches of multilevel trade governance. [...]'PETERSMANN, Ernst-Ulrich. Multilevel Judicial Governance as Guardian of the Constitutional Unity of International Economic Law. Loyola of Los Angeles International and Comparative Law Review, v. 30, issue 3, p. $367-$ 418, 2008. p. 247.

67 Assim explicita o autor em um de seus diversos artigos sobre o tema: "WTO law already serves 'constitutional functions': it protects freedom and non-discrimination across frontiers far beyond the unilateral domestic guarantees in all 135 WTO member states. By ensuring legally binding dispute settlement rulings and appellate review within short time-limits, the compulsory WTO dispute settlement system promotes rule of law more effectively than any other worldwide treaty system. The WTO Agreement asserts legal supremacy over the more than 20 worldwide trade agreements listed in the WTO Annexes. It also provides a legal framework for the periodic negotiation of new WTO Agreements. [...] If the WTO Agreement can be linked to a 'constitution', would the legitimacy, democratic acceptability, and legal consistency of WTO law not benefit from including additional constitutional safeguards such as human rights?" PETERSMANN, Ernst-Ulrich. The WTO Constitution and Human Rights. Journal of International Economic Law, v. 3, p. 19-25, 2000. 
Assim, o Sistema de Solução de Controvérsias desempenha um papel essencial na passagem de uma inadequada perspectiva "bobbesiana" do Direito Internacional - como instrumento de coexistência entre os Estados - rumo à construção de um "Direito Internacional da Integração". ${ }^{68}$ Por outro lado, embora existente e necessário, o constitucionalismo relacionado à $\mathrm{OMC}$ estaria limitado pelas concepções obtusas dos membros da Organização, que estariam em violação à disciplina multilateral ao restringir e coibir mecanismos de transparência e accountability em aspectos democráticos e judiciais. ${ }^{69}$

Dessa forma, a perspectiva do constitucionalismo aplicada à OMC, embora sujeita ao subjetivismo de sentidos conferidos pelos autores, é noção que retoma a ligação das regras comerciais com o Direito Internacional como um todo.

Diferentemente de uma visão negativista e maniqueísta que tradicionalmente se aplicava a tal ramo do Direito Internacional, ${ }^{70}$ por meio dessa perspectiva, passa-se a vislumbrar uma relação de pertencimento entre o sistema multilateral de comércio e o sistema jurídico internacional como um todo, ${ }^{71}$ na busca pela concretização das funções mais amplas da normatividade internacional e, portanto, de construção de uma verdadeira comunidade internacional.

Assim, se por um lado a OMC funciona como um fórum de negociação, em aplicação do paradigma tradicional do Direito Internacional de cooperação, por outro lado a sofisticação do Sistema de Solução de Controvérsias pode indicar características de uma organização de integração, em um paradigma de constitucio-

68 PETERSMANN, Ernst-Ulrich. From the Hobbesian International Law of Coexistence to Modern Integration Law: The WTO Dispute Settlement System. Journal of International Economic Law, v. 1, issue 2, p. 175-198, 1998.

69 PETERSMANN, Ernst-Ulrich. Multilevel Judicial Governance as Guardian of the Constitutional Unity of International Economic Law. Loyola of Los Angeles International and Comparative Law Review, v. 30, issue 3, p. 233-270, 2008. p. 248.

70 A exemplo, confira-se o posicionamento de Celso Duvivier de Albuquerque Mello: "[...] As perspectivas que vemos para o Direito Internacional Econômico é que ele é um direito visando a legalizar a exploração dos países pobres pelos ricos. Repetimos, é um ramo do Direito Internacional Público que perden a noção de justiça essencial a todo Direito. Ele é o lado negro do Direito Internacional Público. [...]'MELLO, Celso Duvivier de Albuquerque. Perspectivas do direito internacional econômico. In: CASELLA, Paulo Borba; MERCADANTE, Araminta de (Coord.). Guerra comercial ou integração mundial pelo comércio?: a OMC e o Brasil. São Paulo: LTr, 1998. p. 70-93. p. 93.

71 TRACHTMAN, Joel P. The Constitutions of the WTO. European Journal of International Law, v. 17, n. 3, p. 623-646, 2006. p. 624. nalização do Direito Internacional. ${ }^{72}$

Em um segundo sentido, a perspectiva comunitária também é aplicada à OMC para conceituá-la como uma "comunidade" de direito (Gemeinschaf), ${ }^{73} \mathrm{em}$ análise sociológica de sua constituição, como paradigma substitutivo à perspectiva racionalista. Ambos os sentidos se interconectam. Nessa nova abordagem teórica da OMC, os principais atores do quadro analítico do comércio internacional não são os Estados, ${ }^{74}$ mas a variedade de agentes econômicos individuais - tais como importadores, fornecedores, distribuidores, consumidores etc. - que participam da comunidade do comércio internacional. ${ }^{75}$ Nesse viés, a OMC abarca expectativas dos múltiplos integrantes da comunidade, que possuem objetivos compartilhados na manutenção e respeito ao sistema. ${ }^{77}$

Nese quadro analítico, assumem relevância especial as discussões sobre o Sistema de Solução de Controvérsias da OMC e a responsabilidade internacional no contexto multilateral, uma vez que há na doutrina a percepção de que o elemento de presunção de interesse

72 LAMY, Pascal. The Place of the W'TO and its Law in the International Legal Order. European Journal of International Law, v. 17, n. 5, p. 969-984, 2006. p. 970.

73 CHO, Sungjoon. Beyond Rationality: A Sociological Construction of the World Trade Organization. Virginia Journal of International Law, v. 52, p. 321-354, 2011-2012. p. 321.

74 É necessário destacar que o termo é utilizado nessa sentença para designar os Estados como unidades básicas da sociedade internacional e participantes da OMC, contudo não somente Estados são aceitos como membros da OMC, que está aberta também à acessão de "territórios aduaneiros". Nesse sentido esclarece a primeira das notas explicativas do Acordo Constitutivo da OMC "Entende-se que os termos 'país' e 'países' tais como utilizados no presente Acordo e nos Acordos Multilaterais de Comércio incluem quaisquer territórios aduaneiros autônomos dos membros da OMC." Caso único é o da União Europeia, por sua vez, é membro da OMC em status independente de seus Estados membros, como explica-se adiante.

75 CHO, Sungjoon. Beyond Rationality: A Sociological Construction of the World Trade Organization. Virginia Journal of International Law, v. 52, p. 321-354, 2011-2012. p. 343.

76 MANN, Erika. A Parliamentary Dimension to the WTO: More than Just a Vision. Reforming the World Trading System. In: PETERSMANN, Ernst- Ulrich. Reforming the World Trading System: Legitimacy, Efficiency and Democratic Governance. Oxford: Oxford University Press, 2005. p. 421-428. p. 421.

77 As autoras mencionam valores compartilhados entre os prórpios membros da Organização, debatendo a relevancia da OMC em um referencial teórico de global governance, que possui convergências relevantes com este trabalho: DAIBERT, Letícia de Souza; PERES, Ana Luísa Soares. Governança global e a Organização Mundial do Comércio: desafios impostos pelo novo mandato de desenvolvimento. Revista de Direito Internacional, Brasília, v. 11, n. 2, p. 217-238, 2014. p.217-238. 
econômico ou jurídico na instauração de procedimentos de solução de controvérsias simbolizaria a confirmação da hipótese de comunitarização da OMC. ${ }^{78}$

Isto é, o fato de cada membro ser capaz de acionar a responsabilização por violação da normativa multilateral ainda que não tenha interesse direto ou pessoal, explicita a existência de um interesse "comunitário" ou interesse "sistêmico" no respeito à legalidade. ${ }^{79}$ Essa faceta de institucionalização da responsabilidade internacional no sistema multilateral de comércio simbolizaria uma primazia do respeito ao direito em substituição à lógica de reparação, em valorização aos interesses comuns. ${ }^{80} 81$

Em ambos os sentidos, a perspectiva comunitária simboliza a passagem da compreensão da OMC em uma lógica contratual e interestatal clássica para uma interpretação das "dimensões constitucionais" do sistema multilateral de comércio, em face aos agentes econômicos individuais integrantes da comunidade do comércio internacional e como parte do sistema jurídico internacional em um sentido mais amplo. ${ }^{82}$

A comparação com a evolução do ordenamento jurídico comunitário europeu é oportuna, e não escapa a di-

78 Embora seja crescente essa interpretação, há também ceticismo em relação à extensão do significado dessa presunção. Nesse sentido, Alberto do Amaral Junior afirma "Na conjuntura atual, o prejuizo indireto decorrente de um interesse sistêmico não permite ao membro exercer o papel de ministério público nem lhe faculta propor uma espécie de actio popularis para a defesa do interesse público na OMC." AMARAL JÚNIOR, Alberto do. A solução de controvérsias na OMC. São Paulo: Atlas, 2008. p. 107.

79 LAFER, Celso. A OMC e a regulamentação do comércio internacional: uma visão brasileira. Porto Alegre: Livraria do Advogado, 1998. p. 134

80 "An important, and in many ways innovative, feature of this system is the presumption of legal and economic interest in bringing proceedings, which confirms the hypothesis of a 'communitization' of WTO law: each Member State can enforce WTO law whether or not it has a direct and personal interest - in the interests, so to speak, of the 'community of states parties'. [...]'LAMY, Pascal. The Place of the WTO and its Law in the International Legal Order. European Journal of International Law, v. 17, n. 5, p. 969-984, 2006. p. 976.

81 Para uma discussão acerca dessa lógica atual de responsabilidade e das possibilidades de melhora, Cf: ELIAS, Fernando Lopes Ferraz. Os mecanismos de indução ao cumprimento no âmbito da OMC. Revista de Direito Internacional, Brasília, v. 11, n. 2, p. 257-279, 2014. VIDIGAL, Geraldo. Re-assessing WTO Remedies: The Prospective and the Retrospective. Journal of International Economic Law, v. 16, issue 3, 505-534, Jul. 2013.

82 PETERSMANN, Ernst-Ulrich. Multi-Level Judicial Trade Governance without Justice? On the Role of Domestic Courts in the WTO Legal and Dispute Settlement System. EUI Working Paper $L A W$, n. 44, p. 8, 2006. PETERSMANN, Ernst-Ulrich. Multilevel Judicial Governance as Guardian of the Constitutional Unity of International Economic Law. Loyola of Los Angeles International and Comparative Law Review, v. 30, issue 3, p. 367-418, 2008. versos doutrinadores, ${ }^{83}$ que buscam na União Europeia preciosas lições para o futuro do Direito Internacional. ${ }^{84}$ Assim como o atual Tribunal de Justiça da União Europeia (TJUE) ${ }^{85}$ foi essencial no desenvolvimento da ordem jurídica comunitária - ${ }^{86}$ transformando tratados originariamente intergovernamentais, através de interpretações constitucionais centradas no cidadão, em ins-

83 SLAUGHTER, Anne-Marie; BURKE-WHITE, William. Future of International Law Is Domestic (or, the European Way of Law). Harvard International Law Journal, v. 47, p. 327-352, 2006. HSUEH, Ching-wen. Direct Effect, WTO Compliance Mechanism and the Protection for Individuals: Lessons Learned from the EC. Asian Journal of WTO \& International Health Law and Policy, v. 4, issue 2, p. 521-556, Sep. 2009. PETERSMANN, Ernst-Ulrich. From the Hobbesian International Law of Coexistence to Modern Integration Law: The WTO Dispute Settlement System. Journal of International Economic Law, v. 1, issue 2, p. 175-198, 1998. PETERSMANN, Ernst-Ulrich. Multilevel Judicial Governance as Guardian of the Constitutional Unity of International Economic Law. Loyola of Los Angeles International and Comparative Law Review, v. 30, issue 3, p. $367-$ 418, 2008. PETERSMANN, Ernst-Ulrich. PETERSMANN, ErnstUlrich. The Future of the WTO: From Authoritarian Mercantilism to Multilevel Governance for the Benefit of Citizens. Asian Journal of WTO \& International Health Law and Policy, v. 6, issue 1, p. 45-80, Mar. 2011.

84 Embora não se tenha o objetivo de discutir as causas e o alcance da crise econômica com a qual tem se deparado a União Europeia, é relevante destacar que tal crise não desabona o significativo desenvolvimento normativo-institucional do ordenamento jurídico comunitário, com características ímpares como: primazia do direito comunitário, direta aplicabilidade, acesso ao sistema jurisdicional e aplicação de direitos e garantias supranacionais. Desse modo, a crise não abala a capacidade dessa ordem jurídica de oferecer modelos de mecanismos e instrumentos bem sucedidos, especialmente no que tange à lógica diferenciada de relação entre o Direito Internacional (comunitário) e o direito interno dos Estados membros.

85 Referimo-nos ao Tribunal de Justiça da União Europeia (TJUE) como o órgão jurisdicional principal da atual União Europeia. Sua configuração modificou-se com o passar do tempo, assim como sua nomenclatura, uma vez que era anteriormente designado Tribunal de Justiça das Comunidades Europeias (TJCE). O trabalho não faz diferenciação precisa entre eles, e pela compreensão de continuidade, nos referimos também por meio da sigla TJUE/TJCE.

86 Cita-se jurisprudência paradigmática nesse sentido, por exemplo: Caso Van den et Loos, no qual TJUE reconheceu a Comunidade como constitutiva de uma "Nova Ordem Jurídica" de direito internacional, " [...] pelo fato de os Estados terem limitado seus direitos soberanos, ainda que em áreas limitadas, e os sujeitos que lhe estão subordinados não constituem somente os Estados-membros, mas também seus nacionais" Van Gend en Loos v. Administratie der Belastingen (Rec.1963, p.1), Case 26/62, 05 fev. 1963. p. 3. Também é relevante a posição explicitada no caso Costa-E.N.E.L: "Ao criar uma comunidade de duração ilimitada, detentora de suas próprias instituições, sua própria personalidade, sua própria capacidade e capacidade de representação no plano internacional e, particularmente, poderes reais oriundos de uma limitação de soberania ou uma transferência de poderes dos Estados para a comunidade, os Estados Membros limitaram seus poderes, ainda que em áreas limitadas, e criaram um corpo de direito que subordina tanto seus nacionais quanto os próprios Estados." Costa / E.N.E.L. (Rec.1964, p.585), Case 6/64, 15 jul. 1964. p. 1141. 
trumentos constitucionais de proteção da comunidade e dos direitos individuais - acredita-se que o Sistema de Solução de Controvérsias possa de fato desempenhar papel central na comunitarização da OMC. ${ }^{87}$

Contudo, é preciso diferenciar aspectos descritivos e prescritivos do fenômeno em análise. Isto é, por um lado, nos Acordos Regionais de Comércio a promoção de segurança nas relações econômicas internacionais através de mecanismos de solução de controvérsias constitui-se como um de seus elementos essenciais. No entanto, em contraste com o Direito Comunitário, o Direito Internacional emanado da OMC é classicamente compreendido como fonte de direitos e obrigações entre Estados, em desconsideração a direitos individuais. ${ }^{88}$

Essa perspectiva- que se mostra prevalente na academia, nos quadros da OMC e na diplomacia dos diferentes Estados, pode ser superada, por meio da interpretação constitucional, conforme explicitada supra. Destaca-se, inclusive, o papel central que a academia exerce na própria construção de uma agenda comunitária no paradigma do constitucionalismo.

Desse modo, Ernst-Ulrich Petersmann destaca que a realização dos objetivos mais amplos do sistema multilateral e de seu sistema de solução de controvérsia, relacionados à segurança e previsibilidade, só pode se dar em plenitude sob uma perspectiva focada no cidadão, a partir de reformas que promovam uma governança coerente entre esse Sistema de Solução de Controvérsias e os órgãos domésticos. ${ }^{89}$

Ademais, as obrigações dos membros da OMC não podem ser interpretadas descontextualizadas de obri-

87 PETERSMANN, Ernst-Ulrich. De-Fragmentation of International Economic Law through Constitutional Interpretation and Adjudication with Due Respect for Reasonable Disagreement. Loyola University Chicago International Law Review, v. 6, issue 1, p. 209-248, 2008-2009.

88 PETERSMANN, Ernst-Ulrich. Multi-Level Judicial Trade Governance without Justice? On the Role of Domestic Courts in the WTO Legal and Dispute Settlement System. EUI Working Paper $L A W$, n. 44, p. 9, 2006.

89 PETERSMANN, Ernst-Ulrich. Multi-Level Judicial Trade Governance without Justice? On the Role of Domestic Courts in the WTO Legal and Dispute Settlement System. EUI Working Paper $L A W$, n. 44, p. 12, 2006. gações prescritas na Carta da ONU, ${ }^{90}{ }^{91}$ tais como o respeito à justiça e observância dos direitos humanos e liberdades fundamentais. Isto é, o sistema jurídico internacional coexiste como um todo e as organizações internacionais - dentre elas a OMC - são aspectos integradores do constitucionalismo global e se prestam à concretização da ideia de comunidade internacional.

\section{Considerações Finais}

Apesar de não ser uma ideia recente, a renovada interpretação conferida à teoria do constitucionalismo no Direito Internacional apresenta relevância no contexto de juridificação e jurisdicionalização das diferentes temáticas, dentre elas o comércio internacional.

Embora não sem resistência, a perspectiva do constitucionalismo é uma concepção recentemente aplicada ao sistema multilateral de comércio, buscando vislumbrar na OMC facetas prospectivas e preceptivas desse fenômeno. Diretamente vinculada a essa matriz teórica, encontra-se a ideia de comunitarização da OMC, que se apresenta como uma possibilidade de reinvenção do sistema multilateral de comércio, mas que exigiria diversas transformações por parte de seus membros.

Como se buscou salientar, a evolução da realidade internacional e dos diferentes paradigmas de Direito Internacional que sob elas recaem tem se dado de modo a concretizar a noção de comunidade internacional, que se constrói para além do voluntarismo dos Estados e necessariamente incluindo os sujeitos que antes tinham atuação apenas no interior dos Estados.

O Direito Internacional contemporâneo busca se reerguer em novos fundamentos, que levem em conta valores essenciais da humanidade como um todo, o que exige que o Direito Internacional seja traduzido em es-

90 BRASIL. Carta da ONU. Decreto no 19.841, 22 out. 1945, que promulga a Carta das Nações Unidas, da qual faz parte integrante o anexo Estatuto da Corte Internacional de Justiça, assinada em São Francisco, a 26 de junho de 1945, por ocasião da Conferência de Organização Internacional das Nações Unidas. Disponível em: <http://www.planalto.gov.br/ccivil_03/decreto/1930-1949/ d19841.htm>. Acesso em: 10 fev. 2016.

91 BRASIL. Convenção de Viena sobre o Direito dos Tratados. Versão oficial em português segundo o decreto n. 7.030, 14 dez. 2009, que promulga a Convenção de Viena sobre o Direito dos Tratados, concluída em 23 de maio de 1969, com reserva aos Artigos 25 e 66. Disponível em: < http://www.planalto.gov.br/ccivil_03/_ato20072010/2009/decreto/d7030.htm>. Acesso em: 10 fev. 2016. 
truturas, instituições e mecanismos que abarquem níveis de normatividade e governança que alcancem o cidadão. Esse quadro demanda, assim, uma reestruturação da ordem jurídica internacional para além dos Estados e também em face dos indivíduos, e, por isso, se destaca a relevância do paradigma constitucionalista do Direito Internacional.

Embora a concepção de constituição no Direito Internacional não seja recente, a sua aplicação tem sido desenvolvida pela doutrina nas últimas décadas, como um paradigma de substituição à ordem internacional estatocêntrica, e em contraposição à corrente fragmentária, revisitando, assim, a unidade e a coerência como pilares do sistema jurídico internacional.

Assim, a Organização Mundial do Comércio, embora constituída e operacionalizada com o objetivo primordial de liberalização do comércio, não pode ser interpretada de maneira dissociada desse contexto mais amplo do sistema jurídico internacional. A concretização satisfatória de seus objetivos mais amplos e a implementação eficaz das obrigações estabelecidas pelo sistema multilateral de comércio somente tem espaço em uma abordagem que insira a OMC na comunidade internacional, e que portanto leve em conta valores e obrigações que compõem o constitucionalismo global.

Se o constitucionalismo tem se mostrado como perspectiva capaz de substituir as noções problemáticas de soberania e consenso na formação do Direito Internacional por outros fundamentos, considerando parâmetros de legitimidade, democracia e transparência, a OMC pode ser um espaço de consolidação e aplicação do international rule of law que leve em conta os mais diferentes agentes econômicos internacionais - tais como importadores, fornecedores, distribuidores, consumidores, etc. - que participam da comunidade do comércio internacional e que possuem interesses legítimos na construção e efetivação de suas expectativas.

Naturalmente, a aplicação desse paradigma à OMC enfrenta ceticismo e críticas não somente na academia, mas principalmente entre os atores que lidam com a prática do sistema multilateral e que podem tender a interpretá-lo de maneira hermética e "tecnicista". Para além dos obstáculos enfrentados, contudo, há que se destacar o papel central que a academia exerce na própria construção de uma agenda comunitária no paradigma do constitucionalismo, sob uma perspectiva prescritiva e não somente descritiva.
Analisar o Direito Internacional e a Organização Mundial do Comércio sob a perspectiva constitucionalista significa vislumbrá-los como instrumentos universalizantes de transformação positiva da realidade internacional e de concretização de valores e interesses comunitários.

\section{ReferênCIAS BIBLIOGRÁfiCAS}

AMARAL JÚNIOR, Alberto do. A solução de controvérsias na OMC. São Paulo: Atlas, 2008.

BARRAL, Welber. De Bretton Woods a Doha. In: BARRAL, Welber. (Org). O Brasil e a OMC. 2. ed. Curitiba: Juruá, 2006.

BARRAL, Welber; PRAZERES, Tatiana. Solução de controvérsias. In: BARRAL, Welber. (Org). O Brasil e a OMC. 2. ed. Curitiba: Juruá, 2006. p. 27-46.

BRASIL. Carta da ONU. Decreto no 19.841, 22 out. 1945, que promulga a Carta das Nações Unidas, da qual faz parte integrante o anexo Estatuto da Corte Internacional de Justiça, assinada em São Francisco, a 26 de junho de 1945, por ocasião da Conferência de Organização Internacional das Nações Unidas. Disponível em: <http://www.planalto.gov.br/ccivil_03/decreto/1930-1949/d19841.htm>. Acesso em: 10 fev. 2016.

BRASIL. Convenção de Viena sobre o Direito dos Tratados. Versão oficial em português segundo o decreto n. 7.030, 14 dez. 2009, que promulga a Convenção de Viena sobre o Direito dos Tratados, concluída em 23 de maio de 1969, com reserva aos Artigos 25 e 66. Disponível em: <http:/ / www.planalto.gov.br/ccivil_03/_ato2007-2010/2009/decreto/d7030.htm>. Acesso em: 10 fev. 2016.

CAPUCIO, Camilla. Apontamentos sobre Francisco de Vitória e Francisco Suarez: construção doutrinária e fundamento do jus gentium. In: MENEZES, Wagner. (Org.). Direito internacional clássico e seu fundamento. Belo Horizonte: Arraes Editores, 2014. p. 62-74.

CARREAU, Dominique; JUILLARD, Patrick. Droit International Économique. Paris: Dalloz, 2007.

CASELLA, Paulo Borba. Direito internacional pós-moderno $e$ a revisão dos modelos institucional e normativo. In: CASELLA, Paulo Borba. BRIC-Brasil, Rússia, Índia, China e Africa do Sul: uma perspectiva de cooperação internacional. São Paulo: Atlas, 2011. p. 113-137. 
CASELLA, Paulo Borba. Fundamentos e perspectivas do direito internacional pós-moderno. Revista da Faculdade de Direito da Universidade de São Paulo, São Paulo, p. 433-466, jan./dez. 2006.

CASS, Deborah Z. The "Constitutionalization" of International Trade Law: Judicial Norm-Generation as the Engine of Constitutional Development in International Trade'. European Journal of International Law, v. 12, p. 3975,2001

CHO, Sungjoon. Beyond Rationality: A Sociological Construction of the World Trade Organization. Virginia Journal of International Law, v. 52, p. 321-354, 2011-2012.

CLODOVIL, Leonor Augusta Giovine. O interesse público no Antidumping. 2009. 345 f. Tese (Doutorado em Direito) - Faculdade de Direito, Universidade de São Paulo, São Paulo, 2009.

COHEN, Harlan Grant. From Fragmentation to Constitutionalization. Pacific McGeorge Center for Global Business and Development Law Journal, v. 25, p. 381-394, 2012.

DAIBERT, Letícia de Souza; PERES, Ana Luísa Soares. Governança global e a Organização Mundial do Comércio: desafios impostos pelo novo mandato de desenvolvimento. Revista de Direito Internacional, Brasília, v. 11, n. 2, p. 217-238, 2014.

DUNOFF, Jeffrey L. Constitutional Conceits: The W'TO's 'Constitution' and the Discipline of International Law. European Journal of International Law, v. 17, n. 3, p. 647-675, 2006.

DUNOFF, Jeffrey L. Why Constitutionalism Now? Text, Context and the Historical Contingency of Ideas. Journal of International Law and International Relations, v. 1, p. 191-211, 2004-2005.

DUPUY, Pierre-Marie. L'unité de l'ordre juridique international: cours général de droit international public. Recueil des cours, v. 297, p. 9-489, 2002.

DUPUY, Pierre-Marie. The Constitutional Dimension of the Charter of the United Nations Revisited. Max Planck Yearbook of United Nations Law, v. 1, p. 1-32, 1997.

ELIAS, Fernando Lopes Ferraz. Os mecanismos de indução ao cumprimento no âmbito da OMC. Revista de Direito Internacional, Brasília, v. 11, n. 2, p. 257-279, 2014.

FERRAJOLI, Luigi. A soberania no mundo moderno: nascimento e crise do Estado nacional. São Paulo: M. Fontes, 2002.
FIGUEIREDO, Celso Henrique Cadete de. A promoção de accountability na Organização Mundial do Comércio: uma análise horizontal e vertical. Revista de Direito Internacional, Brasília, v. 11, n. 2, p. 279-309, 2014.

FRIEDMANN, Wolfgang. The Changing Structure of International Law. New York: Columbia University Press, 1964.

FROWEIN, Jochen A. Reactions by Not Directly Affected States to Breaches of Public International Law. Recueil des cours, v. 248, p. 349-445, 1994.

HSUEH, Ching-wen. Direct Effect, WTO Compliance Mechanism and the Protection for Individuals: Lessons Learned from the EC. Asian Journal of WTO \& International Health Law and Policy, v. 4, issue 2, p. 521-556, Sep. 2009.

JACKSON, John H. The Great 1994 Sovereignty Debate: United States Acceptance and Implementation of the Uruguay Round Results. Columbia Journal of Transnational Law, v. 36, p. 157-188, 1998.

JACKSON, John H. The WTO "Constitution" and Proposed Reform: Seven "Mantras" Revisited. Journal of International Economic Law, v. 4, p. 67-78, 2001.

JACKSON, John. Sovereignty, the WTO and Changing Fundamentals of International Law. New York: Cambridge University Press, 2006.

JACKSON, Jonh H. The Jurisprudence of GATT and the WTO. Cambridge: Cambridge University Press, 2000.

LAFER, Celso. A OMC e a regulamentação do comércio internacional: uma visão brasileira. Porto Alegre: Livraria do Advogado, 1998.

LAFER, Celso. O Gatt, a cláusula de nação mais favorecida e a América Latina. Boletim da Sociedade Brasileira de Direito Internacional, n. 55/60, p. 133-151, 1972-1974.

LAFER, Celso. O sistema de solução de controvérsias da Organização Mundial do Comércio. In: CASELLA, Paulo Borba; MERCADANTE, Araminta de (Coord.). Guerra comercial ou integração mundial pelo comércio?: a OMC e o Brasil. São Paulo: LTr, 1998. p. 729-755.

LAMY, Pascal. The Place of the WTO and its Law in the International Legal Order. European Journal of International Law, v. 17, n. 5, p. 969-984, 2006.

LAUTERPACHT, Hersch. Règles générales du droit de la paix. Recueil des cours, v. 62, p. 95-422, 1937. 
LAUTERPACHT, Hersch. The international protection of human rights. Recueil des cours, v. 70, p. 1-108, 1947.

MANN, Erika. A Parliamentary Dimension to the WTO: More than Just a Vision. Reforming the World Trading System. In: PETERSMANN, Ernst- Ulrich. Reforming the World Trading System. Legitimacy, Efficiency and Democratic Governance. Oxford: Oxford University Press, 2005. p. 421-428.

MCGINNIS, John O.; MOVSESIAN, Mark L. The World Trade Constitution. Harvard Law Review, v. 114, issue 2, p. 511-605, Dec. 2000.

MELLO, Celso Duvivier de Albuquerque. Perspectivas do direito internacional econômico. In: CASELLA, Paulo Borba; MERCADANTE, Araminta de (Coord.). Guerra comercial ou integração mundial pelo comércio?: a OMC e o Brasil. São Paulo: LTr, 1998. p. 70-93.

MENEZES, Wagner. A Jurisdicionalização do direito internacional: conflitos de competência entre tribunais internacionais, sua prevenção e resolução. 2011. 513 f. Tese (Doutorado) - Faculdade de Direito, Universidade de São Paulo, São Paulo, 2011.

MENEZES, Wagner. Ordem global e transnormatividade. Ijuí: Unijuí, 2005.

MENEZES, Wagner. Tribunais Internacionais: jurisdição e competência. São Paulo: Saraiva, 2013.

ORGANIZAÇÃO MUNDIAL DO COMÉRCIO. Acordos e documentos. Disponível em: <www.wto.org>. Acesso em: 10 fev. 2016.

ORGANIZAÇÃO MUNDIAL DO COMÉRCIO. Legal Affairs Division. WTO analytical index: Guide to WTO Law and Practice. Disponível em: <http://www. wto.org/english/res_e/booksp_e/analytic_index_e/ analytic_index_e.htm>. Acesso em: 10 fev. 2016.

PETERS, Anne. The merits of global Constitutionalism. Indiana Journal of Global Legal Studies, v. 16, p. 397411, 2009.

PETERS, Anne; ARMINGEON, Klaus. IntroductionGlobal Constitutionalism from an Interdisciplinary Perspective. Indiana Journal of Global Legal Studies, v. 16, p. 385-395, 2009.

PETERSMANN, Ernst-Ulrich. From the Hobbesian International Law of Coexistence to Modern Integration Law: The W'TO Dispute Settlement System. Journal of International Economic Law, v. 1, issue 2, p. 175-198, 1998.
PETERSMANN, Ernst-Ulrich. How to Constitutionalize International Law and Foreign Policy for the Benefit of Civil Society? Michigan Journal of International Law, v. 20, p. 1-30, 1998. p. 13.

PETERSMANN, Ernst-Ulrich. Human Rights, International Economic Law and Constitutional Justice: A Rejoinder. European Journal of International Law, v. 19, issue 5, p. 955-960, 2008.

PETERSMANN, Ernst-Ulrich. Legal, Economic and Political Objectives of National and International Competition Policies: Constitutional Functions of WTO "Linking Principles" for Trade and Competition. New England Law Review, v. 34, p. 145-162, 1999.

PETERSMANN, Ernst-Ulrich. Multilevel Judicial Governance as Guardian of the Constitutional Unity of International Economic Law. Loyola of Los Angeles International and Comparative Law Review, v. 30, issue 3, p. 367-418, 2008.

PETERSMANN, Ernst-Ulrich. The Future of the WTO: From Authoritarian Mercantilism to Multilevel Governance for the Benefit of Citizens. Asian Journal of WTO \& International Health Law and Policy, v. 6, issue 1, p. 45-80, Mar. 2011.

PETERSMANN, Ernst-Ulrich. The WTO Constitution and Human Rights. Journal of International Economic Law, v. 3, p. 19-25, 2000.

RANGEL, Vicente Marotta. Francisco de Vitoria y el Federalismo Internacional. In: MANGAS MARTÍN, Araceli. La Escuela de Salamanca y el Derecho Internacional en America: del Passado al Futuro. Salamanca: Asociacion Espanola de Professores de Derecho Internacional, 1993. p. 205-214.

SCELLE, Georges. Règles générales du droit de la paix. Recueil des cours, v. 46, p. 327-703, 1933.

SCHWARZENBERGER, Georg. The fundamental principles of international law. Recueil des cours, v. 87, p. 191-385, 1955.

SCHWARZENBERGER, Georg. The principles and standards of international economic law. Recueil des cours, v. 117, p. 1-98, 1966.

SILVA, Elaini Cristina Gonzaga da. Juridicização das relações internacionais e solução de controvérsias: análise do sistema multilateral de comércio. 2007. 225 f. Dissertação (Mestrado em Direito) - Faculdade de Direito, Universidade de São Paulo, São Paulo, 2007. 
SILVA, Roberto Luiz. Direito econômico internacional e direito comunitário. Belo Horizonte: Del Rey, 1995.

SIMMA, Bruno. From bilateralism to community interest in international law. Recueil des cours, v. 250, p. $217-$ 384, 1994.

SLAUGHTER, Anne-Marie; BURKE-WHITE, William. Future of International Law Is Domestic (or, the European Way of Law). Harvard International Law Journal, v. 47, p. 327-352, 2006.

THORSTENSEN, Vera. OMC - Organização Mundial do Comércio: as regras do comércio internacional e a nova rodada de negociações multilaterais. 2. ed. São Paulo: Aduaneiras, 2001.

TOMUSCHAT, Christian. International law: ensuring the survival of mankind on the eve of a new century. General course on public international law. Recueil des cours, v. 281, p. 9-438, 1999.

TRACHTMAN, Joel P. The Constitutions of the WTO. European Journal of International Law, v. 17, n. 3, p. 623646, 2006.

TRINDADE, Antônio Augusto Cançado. International law for humankind: towards a new jus gentium (II). General course on public international law. Recueil des cours, v. 317, p. 9-312, 2005.
VAN AAKEN, Anne. Defragmentation of Public International Law Through Interpretation: A Methodological Proposal. Indiana Journal of Global Legal Studies, v. 16, p. 483-512, 2009.

VERDROSS, Alfred. Le fondement du droit international. Recueil des cours, v. 16, p. 247-323, 1927.

VILLALPANDO, Santiago. The Legal Dimension of the International Community: How Community Interests Are Protected in International Law? European Journal of International Law, v. 21, n. 2, p. 387-419, 2010.

WALDOCK, Humphrey. General course on public international law. Recueil des cours, v. 106, p. 1-251, 1962.

YASUAKI, Onuma. A Transcivilizational Perspective on International Law. Questioning Prevalent Cognitive Frameworks in the Emerging Multi-Polar and Multi-Civilizational World of the Twenty-First Century. Recueil des cours, v. 342, p. 77-418, 2010.

ZACHER, Mark. The Decaying pillars of the Westphalian temple: Implications for International Order and Governance. In: ROSENAU, James; CZEMPIEAL, Ernst-Otto. Governance, Order and Change in World Politics. Cambridge: University Press, 1992. p. 58-101. 
Para publicar na Revista de Direito Internacional, acesse o endereço eletrônico www.rdi.uniceub.br ou www.brazilianjournal.org.

Observe as normas de publicação, para facilitar e agilizar o trabalho de edição. 